LSE 'Europe in Question’ Discussion Paper Series

\title{
On Building the American and the
}

\section{European Empires}

Josep M. Colomer

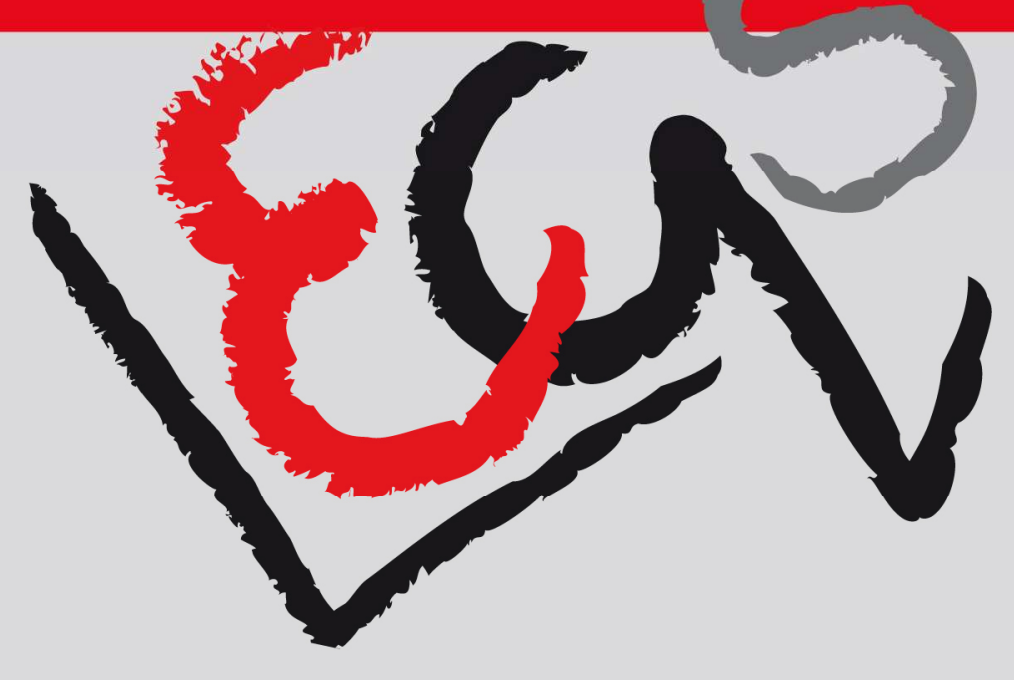




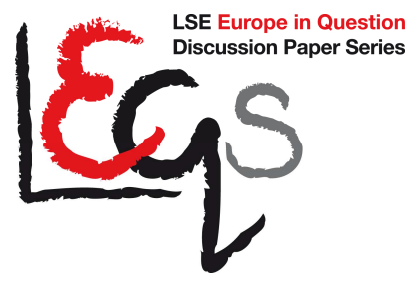

\section{Editorial Board}

Dr. Joan Costa-i-Font

Dr. Vassilis Monastiriotis

Dr. Jonathan White

Ms. Katjana Gattermann

All views expressed in this paper are those of the author and do not necessarily represent the views of the editors or the LSE.

(C) Josep M. Colomer 


\title{
On Building the American and the
}

\section{European Empires}

\author{
Josep M. Colomer*
}

\begin{abstract}
The processes of building the United States of America (USA) during the nineteenth century and the European Union (EU) since mid-twentieth century are among the major claims for the possibility of a vast, 'imperial'-size political unit based on democratic principles. The crucial period for the consolidation of the USA was between the Civil War and the First World War, when it established clear territorial limits and completed its internal institutionalization as a federal democratic union. While the EU has achieved higher levels of economic integration on some issues than the USA did one hundred years ago, it still recognizes a number of additional candidates to become member-states and has not attained a stable constitutional framework. As it was the case for the USA about a century ago, for the current European Union putting an end to the process of territorial expansion and fixing neat external frontiers seems to be a necessary condition to achieve internal institutional stability and robust federal formulas.
\end{abstract}

\footnotetext{
* Higher Council of Scientific Research, Barcelona, 2009

Correspondence:

Universitat Pompeu Fabra

Economics

Ramon Trias Fargas 25

08005 Barcelona, Spain

Email: josep.colomer@gmail.com
} 
On Building the American and the European Empires

\section{Table of Contents}

Abstract

1. Building states from empires and vice versa 3

2. Delimiting the territory 5

2.1. The United States expansion $\quad 7$

2.2. The European Union enlargement 11

$\begin{array}{lr}\text { 3. Institutionalization } & 14\end{array}$

3.1. The states in the USA $\quad 15$

3.2. The states in the EU 17

4. Designing a Federation 20

4.1. American Union 22

4.2. European Union 23

5. Concluding comments 24

References 


\section{On Building the American and the}

\section{European Empires}

\section{Building states from empires and vice versa}

The notion of 'empire' can account for the historical and present configurations of the United States of America (USA) and of the European Union (EU). The processes of building these two large polities have shared important defining characteristics of 'empire' which, in contrast to those defining a sovereign 'state', can be summarized as follows:

- Very large size, in terms of both territory and population.

- Absence of fixed or permanent boundaries. Empires tend to expand over the territory, up to the point of conflict with other empires, and when in decline they may also contract.

- A compound of diverse groups and territorial units. In ancient and medieval times, an empire could be comprised of cities, republics, counties, principalities, bishoprics, and other varied forms of political organization. Democratic empires may also include political units organized with different forms of parliamentary or presidential, unichamber or multichamber, monarchical or republican governments. Today, multiethnic federations can be arranged with less heterogeneous institutional regimes. But they may be linked to the center by diverse institutional formulas.

- A set of multilevel, often overlapping jurisdictions. Within an empire, no authority typically rules with exclusive powers. Rather, the central government may rule indirectly through local governments; the latter develop self-government on important issues; and power sharing is widespread. 
In contrast to 'empire', the 'state' is a form of government that can be defined by the following characteristics:

- Large or middle-sized, in terms of both territory and population.

- Fixed territory and formal boundaries. The clear establishment and foreign recognition of the territorial limits of a state are intended as protection from external attacks, invasions, immigrants, and imports.

- Sovereignty. The state has supreme authority over a territory and population. It recognizes no other source of jurisdiction but itself. The state's power to make ultimate decisions is recognized by other sovereign states.

- Monopoly and homogenization. The state has reserved functions with exclusive jurisdiction within its territory. Whether dictatorial or democratic, it is organized with an internal hierarchy of powers. In order to facilitate the exercise of its functions and consummate its exclusiveness, it tends to establish a uniform administration over the territory, as well as to promote the homogenization of important social and cultural characteristics of its subjects or citizens.

As can be seen, these defining characteristics of empire and state are mutually exclusionary. Together with the other classical category of 'city' (a small, rather homogeneous, self-governed community), they can account for all polities in human history.

Actually, the first modern states emerged from and consolidated themselves against previously existing empires. Both the states in North America having proclaimed their independence from the British dominion and the states in Europe which would eventually join the Union had affirmed their 'sovereignty' since the eighteenth century. Sovereignty was conceived as an absolute, perpetual, inalienable and indivisible power, the supreme source of authority within a well-defined territory. Then, building a new continent-wide empire implied renouncing the previously self- 
assured states' right to make final decisions on all the issues in favour of some distribution of powers among multiple levels of government each with different responsibilities.

An empire can be conceived as a federation in the making to the extent that the process of coordinating diverse political units across a very large and varied territory may lead to the adoption of more stable and more democratic institutional formulas. Although the design of a large federation for the United States of America was already done by late eighteenth century, actually the USA did not attain fixed borders and stable federal institutions until early twentieth century, as we will review in the following pages. The European Union is still in the 'imperial' stage of federation-design and building. I will argue that there is strong relationship between external territorial consolidation and internal institutional arrangement. As happened with the USA, the internal stability and efficiency of the EU will largely depend on the establishment of stable external territorial limits and of an internal democratic system of 'vertical' and 'horizontal' divisions of powers.

\section{Delimiting the territory}

As typical of empires, and in contrast to an essential feature of sovereign states, there are no territorial limits in the United States constitution or in the European Union treaties. The real limits of both unions depend on the capacity of assimilation of new territories located at long distances from the initial core and with significant differences in economic structures and ethnic composition of the population regarding the previous ones. In general, the farther away and the more different the new territories from the founding ones, the less integrative and more coercive the means by which they can be incorporated into the empire. As a consequence, in both processes of building the USA and the EU, the territorial expansion of the initial core eventually slowed down until it reached substantial stability. 
For the United States, the process of annexing the bulk of its current territory since the initial 13 colonies became independent states took more than 60 years - between approximately 1787 and 1850--. The territory of the initial core was finally multiplied by about four. But the population in the original territories at the time of independence from Britain is about half of total population. For the European Union, the process of enlargements from its initial 6 member-states, which started formally in 1957, has already lasted more than 50 years, while several large territories remain potential subjects for further inclusion. So far, the initial territory of the founding members (not counting their former colonies overseas) has been multiplied by three. But like in the U.S., the population of the six initial EU member-states is about half of total population.

\subsection{The United States expansion}

The process of building the United States of America involved sustained fights against the European colonial empires in the Americas, initially Great Britain, of course, but also France and Spain, and later and in the periphery, the Russian and the Japanese empires. Four types of processes of expansion of the USA can be distinguished by territories increasingly distant from the initial core, which have been implemented in different periods. Each model involves different degrees of coercion, from more integration to greater violence. They can be called decolonization, purchase, infiltration, and invasion, respectively.

British colonies had been established in North America since the beginning of the 17th century (with Virginia having been set up in 1619). Their consolidation during the 18th century involved major conflicts with France, especially the so-called 'Great War for Empire' or 'French and Indian War' (1754-63), after which the territories to the east of the Mississippi river were left in the hands of Britain, while those to the west of that river were taken from France and given to Spain. 
A so-called Continental Congress, formed by representatives of thirteen of the British colonies along the Atlantic coast, declared independence in 1776. The union was initially created mainly as a mechanism of self-protection from Britain. When the war for independence was won in 1783, the initial territory of the thirteen colonies was enlarged to more than double the area, with other British lands located to the north and to the west of the Appalachian Mountains until the Mississippi.

The independentists aspired to include Canada. In the Articles of Confederation, they stated: "Canada acceding to this confederation, and adjoining in the measures of the United States, shall be admitted into, and entitled to all the advantages of this Union". During the subsequent war with Britain, United States troops went further north and occupied Montreal and large parts of Quebec. But the British managed to defend their Northern colonies from independence for another eighty years. A settlement would be achieved between the UK and the USA in 1818 to establish the border with Canada along the 49th parallel, that is, crossing the Great Lakes so as for both sides to have access to them. Thus, most further U.S. expansion headed southand west-wards. The 'frontier', that is, the disputed regions at the edges of the settled area, shifted towards the Pacific and the Gulf of Mexico for many years.

The Continental Congress established that the United States would enlarge not by the expansion of existing states but by the creation or admission of new states. The initial thirteen colonies approved new state constitutions in the process of approving the United States constitution in 1789. But the rest of the territory, that is, about half of the total area separated from Britain, remained under the control of the new central authority in Washington for several decades. Eleven new U.S. states were eventually formed there within a period of sixty years.

After the former French colonies west of Mississippi, which had been given to Spain, were devolved to France in 1800, the government of the United States purchased them from Napoleon Bonaparte in 1803 for \$15 million. The Louisiana territory was in fact the west side of the basin of the Mississippi and Missouri rivers, which was bounded to the west by the Rocky Mountains, to the north by the remaining British colony in Canada, and to the south by the colony of New Spain. With the purchase of 
Louisiana, the United States doubled its territory. Eleven new U.S. states were eventually formed there within a period of more than one hundred years.

Another major purchase was Florida, which had been devolved to Spain after independence. It was acquired by the United States in 1819, in exchange for renouncing claims to Texas and \$5 million. Finally, the United States purchased Alaska from the Russian empire in 1867, for $\$ 7.2$ million. In spite of its territorial discontinuity with the rest of the country, it became a U.S. organized territory in 1912 and a U.S. state in 1959. Other proposed purchases emerged among political and entrepreneurial circles of the United States by the mid 19th century, including, most prominently, Cuba. But they were never substantiated.

Another pattern of decolonization of neighbouring or nearby territories can be identified for a number of cases, which includes the following steps. First, American traders, explorers or settlers, usually with high entrepreneurial and productive spirit, establish themselves in a foreign territory. Eventually they become a pressure group or a political force which, in alliance with local groups, is able to challenge the foreign power dominion or overthrow the existing local government and declare an independent republic. Third, the U.S. army intervenes in order to protect the American citizens and re-establish peace. Finally, the territory may be annexed to the United States.

Elements of this model can be identified in several processes in the periphery of the United States. Specifically, in the south, in Texas, which declared its independence from Mexico and formed the 'lone star' republic in 1836, but became a U.S. state in 1845; in the far west, in California, independent from Mexico in 1846 and a U.S. state in 1850, as well as in Oregon, organized as a territory separated from the British in 1848 becoming a U.S. state in 1859; and in the Pacific islands of Hawaii, where the local monarchy was replaced by American residents with a republic in 1893, it became a U.S. territory in 1900, and a state in 1959.

Similar attempts were implemented in Canada, where U.S. 'filibusters' prompted rebellions in 1837, with the aim of establishing a republican government seen as a 
reprise of the American Revolution against the British, but were to no avail. Other infiltrations took place further south, in Panama, which split from Colombia in 1903 and where the canal was put under U.S. control from 1914 on, but it never became annexed.

A number of private armed expeditions were organized by so-called 'filibusters', as mentioned, especially to islands in the Caribbean sea and to Central America, with the aim of expanding the South of the United States into a slave-based tropical empire. They include interventions in Cuba in 1851, Nicaragua in 1855 (where a slave-based dictatorship was enforced for a few years), and Honduras in 1859.

Under the cover of the so-called Monroe doctrine, which, from 1823 onwards, stated that European powers were no longer allowed to colonize or interfere with the affairs of the newly independent states in the Americas, the United States army directly intervened in a number of countries in the Western hemisphere. More than half of the territory of recently independent Mexico until the Rio Grande was incorporated into the United States after a military expedition, which went as far as entering Mexico city in 1848. There were calls for the annexation of "All Mexico," arguing that it would be the best way to ensure future peace in the region, but they were not fulfilled. Mexico withdrew its claims to Texas and was compensated with $\$ 18.2$ million. The annexed territory was rounded out by the Gadsden purchase from Mexico for $\$ 10$ million. Five new U.S. states were eventually formed there within a period of more than sixty years. Again the United States brought troops down to the Rio Grande to put pressure on French emperor Louis Napoleon III to withdraw from Mexico in 1867.

Once the limits of the territory were fixed, institutionalizing the Union required more social and legal unification, particularly regarding the slave-based agrarian South. Initially, the slaves fleeing from the Southern states were caught and sent back to the South by the federal authorities. President Lincoln considered a gradual freeing of slaves, including monetary compensation to their owners, to be sent to Liberia or Panama. But the secession of the Confederate states in the South triggered the Civil War. Lincoln eventually realized that the Union could not be preserved without a 
high degree of legal homogeneity regarding basic human rights, which led him to declare the freedom of slaves. As recently observed by Drew Gilpin Faust:

\begin{abstract}
"In the middle of the nineteenth century, the United States embarked on a new relationship with death, entering into a civil war that proved bloodier than any other conflict in American history, a war that would presage the slaughter of World War I's Western Front and the global carnage of the twentieth century. The number of soldiers who died between 1861 and 1865, an estimated 620,000, is approximately equal to the total American fatalities in the Revolution, the War of 1812, the Mexican War, the Spanish-American War, World War I, World War II, and the Korean War combined. The Civil War's rate of death, its incidence in comparison with the size of the American population, was six times that of World War II. A similar rate, about 2 percent, in the United States today would mean six million fatalities. As the new southern nation struggled for survival against a wealthier and more populous enemy, its death toll reflected the disproportionate strains on its human capital. Confederate men died at a rate three times that of their Yankee counterparts; one in five white southern men of military age did not survive the Civil War...Death created the modern American union - not just by ensuring national survival, but by shaping enduring national structures and commitments."
\end{abstract}

The Reconstruction after the Civil War, however, proved to be more difficult than expected due to resilient divisions within the country. Some politicians thought that an external war against a foreign enemy, namely the remnants of the Spanish empire, could work as an internally unifying drive. By the Spanish-American War in 1898, the United States occupied the penultimate Spanish colonies -four islands or archipelagos in America and Asia--, complemented with compensation of \$20 million. For the first time, none of the annexed territories, all overseas, became a U.S. state, but only colonies and protectorates. Guam remained a U.S. territory. A protectorate was established in Puerto Rico, which became a U.S. territory in 1917 and a 'Commonwealth' in 1952. The Philippines eventually became independent, although as late as 1946. Cuba was independent since 1902, although subjected to several United States direct military interventions and close vigilance of its internal politics until 1934.

The so-called Theodore Roosevelt Corollary to the Monroe Doctrine asserted the right of the United States to intervene in Latin America in cases of "flagrant and chronic wrongdoing by a Latin American nation". Subsequent arbitrating or 
pacifying interventions and occupations were implemented in Nicaragua in 1910-25 and 1927-33, Mexico in 1914 and 1916-17, Haiti in 1915-34, and the Dominican Republic in 1916-24. However, in contrast to the previous processes of enlargement mentioned above, these interventions did not substantiate themselves into the annexation of new territories into the United States. The borders of the empire had been stably established at the Atlantic ocean in the east, Canada and the large enclave of Alaska to the north, around the Gulf of Mexico in the south, and a few islands in the Pacific ocean to the west. The decision by the United States to join the Second World War was triggered precisely by an attack by the Japanese empire on its western border, in Hawaii.

After WWII, the U.S. troops intervened again against revolutionary or populist movements in most countries of their 'backyard', usually in coordination with local political and military groups and only for brief periods. Cases include Guatemala in 1954, Cuba in 1961, the Dominican republic in 1965, and Grenada in 1983, while providing covert aid to domestic counter-revolutionaries in Honduras in 1979-81, El Salvador in 1981-84, and Nicaragua in 1981-89. Yet, again, with these actions, the United States was not trying to expand its territory, but to assert and protect its southern 'frontier' in the Gulf of Mexico, which had in fact become its formal border.

As suggested by the previous overview, the external borders of the American empire were not pre-determined by geography or destiny. Several additional territories could have been included in the Union, while some current members could have remained outside. Specifically, the limits in the north-east corner sought to leave not only the basin of the St. Lawrence river but sufficient overland to Canada to have access to Quebec and Montreal; in the north-west, they implied the split of the former Oregon 'Country' with the British, lately included in the Canadian province of British Columbia; half of California was in, but the other half was out, in Mexico; Puerto Rico was associated to the Union, while the much closer Cuba was not. Not to mention territorially disconnected Alaska and the Pacific archipelagos. 


\subsection{The European Union enlargement}

The union of Europe was initially promoted by the mid-twentieth century, especially by some French and Italian leaders, as a reaction to increasingly frequent and lethal conflicts, especially around the expansionist attempts of the German empire, having culminated in the Second World War in 1939-45. As the most powerful European states began to lose their rival colonial empires overseas, they built a kind of internal, continental empire among themselves for economic and military cooperation. The expansionist policy of the neighbouring Soviet Union in Eastern Europe reinforced the incentives to create a common European defence, in addition to relying upon the military protection of the United States.

The European Union was thus created and has been successively enlarged in response to intra-European conflicts and in competition with the Russian empire. In a similar way to the American case, where the union was developed for reasons of war, mainly as a self-protecting mechanism from the former colonial power, there were also strong military reasons for the initial project of building the United States of Europe.

The union of Europe indeed began as a military enterprise. After the establishment of the North Atlantic Treaty Organization (NATO) led by the United States in 1949, the European partners created the Western European Union. In parallel, a number of international economic agreements among several European states were conceived as being able to reduce competition for strategic resources and in this way prevent some important causes of war. Six states --the large France, Germany, and Italy, and those in the Benelux area comprising Belgium, the Netherlands, and Luxembourg-created the European Coal and Steel Community (ECSC) in 1951, as well as the European Economic Community (EEC) and the European Atomic Energy Community (Euratom) by the Treaty of Rome in 1957. The three economic communities (ECSC, EEC and Euratom) eventually merged into the European Community, which formed a single Council and a single Commission in 1967. 
Building Europe-wide common institutions required a basic consensus among its member states on democratic principles. Further expansions were driven by the aim of establishing durable democracy and aggregating resources by trade rather than by direct military initiatives, which was highly successful in preventing the emergence of motives for new inter-state wars.

The initial core of six member-states of the European Community (EC) was located at the territorial center of the continent, largely coinciding with the lands of Charlemagne's medieval Empire (which later evolved into the Roman and German empire). The first expansions of the EC were implemented towards the west and the south. The candidacy of the United Kingdom was initially rejected in 1961, which implied the withdrawal of its partners in the alternative European Free Trade Association, Denmark, Ireland and Norway. Nevertheless, Denmark, Ireland and the United Kingdom were accepted as new state-members of the EC in 1973. Norway remained out after two failed referendums for membership, although it belongs to the European Economic Space forming a common market and it cooperates with the European institutions on interior and on defence and security policies. In the South, the joining of Greece in 1981 and Portugal and Spain in 1986 after their democratization implied a guarantee against the re-emergence of past dictatorships. With these enlargements, the number of member-states of the European Community doubled to 12 and the initial area (not counting colonies) was multiplied by two and a half. The western and southern frontiers of the Union of Europe were then fixed at the Atlantic ocean and the Mediterranean sea.

After the demise of the Soviet empire and the dissolution of the Soviet Union in 1991, the European Union expanded north- and east-wards. First, the East German territory having formed the so-called German Democratic Republic under Soviet vigilance, was annexed to the Federal Republic of Germany and thus to Europe. Second, the EU incorporated the countries on its previous frontier with the Soviet Union which had remained 'neutral' in foreign policy, Austria, Finland and Sweden, in 1995. Later, it expanded towards newly democratized Eastern European territories which had been members of the German or the Austrian empires in the past and had 
been annexed or satellised by the Soviets as a consequence of World War II. They included three former members of the Soviet Union (Estonia, Latvia and Lithuania), the two former members of the federation of Czecho-Slovakia, one former member of the federation of Yugoslavia (Slovenia), and only four previously independent states (Bulgaria, Hungary, Poland and Romania), up to ten new members, in 2004-2007. All these countries also became NATO members. In contrast, other former members of the Soviet Union with stronger past links with Russia remained outside. Additionally, two small, recently independent British colonies on islands in the Mediterranean, Cyprus and Malta, were also incorporated.

With the current 27 member-states, the initial area of the six founding countries of the European Union has been multiplied by three. The frontiers of the Union are now at the Atlantic ocean in the west, the Mediterranean sea in the south, the Arctic ocean in the north, and near the borders of Turkey and the Russian empire in the east.

Yet, in the south-east corner, in particular, the limits of the European Union are still undefined. A number of civil wars broke out in the Balkans in the process of dissolution of communist-dominated Yugoslavia. The European members of NATO, together with their American allies participated in several military actions to deter violent conflicts, including in Bosnia in 1995 and in Serbia and Kosovo in 1999, followed by the establishment of military missions to keep peace in those territories. Official and officially potential candidates to join the European Union include now all the territories in the Balkans, as well the remaining former members of Yugoslavia, that is, Bosnia-Herzegovina, Croatia, Macedonia, Montenegro, Serbia, and the international protectorate of Kosovo, as enclosed Albania. Most of these countries, with the notorious exception of Serbia, have also been invited to join NATO. All of them already belong to the Stabilization and Association Agreement giving them access to EU markets and financial support.

More controversial is the candidacy of Turkey, another NATO member, which is also subjected to scrutiny regarding its civil rights and democratic credentials. Other possible candidates may include Iceland and Norway, who are also NATO members, and Switzerland, which declined membership in the 1990s on the basis of weak 
internal social support. With all these 38 or so countries, the European Union would multiply the initial area of the 6 founding member states by four (although it would still amount to less than two thirds the area of the United States).

As suggested by the previous overview, the external borders and the internal full membership of the territories of the currently ongoing European empire are not entirely pre-determined by Christendom or by geography. While the northern, western and to some extent southern borders are relatively well established, the eastern limits of the Union are still rivalrous with the neighbouring Russian empire, and dubious regarding the relations with Turkey, the remnant of the Ottoman empire.

A natural eastern border of the EU could be traced around the Black sea and the basins of its rivers, while Russia would be bounded by the Caspian sea and the Volga basin. Also, the Baltic sea and most of its river basins could be a well-defined northern border between Europe and Russia. However, Russia keeps the Baltic enclave of Kaliningrad (built after WWII on the ruins of the Prussian city of Kongsberg), which is encircled by European Union territory and can be accessed only via lands in Lithuania and Belarus. Also, although officially the whole of the island of Cyprus belongs to the European Union, about one third of the territory in the north of the island is a Turkish enclave beyond EU control. In contrast to the United States, therefore, the European Union still has some 'frontiers' to be settled in a more stable way.

\section{Institutionalization}

Delimiting the territories able to be assimilated in an imperial Union is not sufficient. But the institutionalization of all territories under well-integrated and roughly democratic formulas may take a long period. In order for all of the United States territory to be not only annexed but organized as 'states' with self-government, 
On Building the American and the European Empires

about 125 years passed -up to 1912, the eve of World War I--. For the European Union, a complete and stable constitutional formula has not yet been established.

\subsection{The states in the USA}

Within the United States, the territorial limits of each state were drawn, first, on the basis of the former colonies, which in some cases had existed for up to 150 years. Previously existing independent states, such as California and Texas and, of course, Hawaii, also have their own shape. For new lands, however, the criterion was adopted that all states should be created equal in area. In fact, many of the new states are square in shape, measuring 3 or 4 degrees in height and up to 7 degrees in width.

The average state area is 200,000 $\mathrm{km} 2$. The population in the original territories upon independence from Britain (where 25 states eventually formed) is about half of total current population (52\%). Nowadays, the average state in the American union has about 6 million inhabitants (close to the population of the average independent state in the world, which is 6.9 million). The differences, however, are significant: the most populated state, California, with about 37 million, is seventy times more populated than the least one, Wyoming, with 0.4 million.

The basic territorial limits of the American Union had been fixed by the mid-19th century, as mentioned, making "a country large enough for a great empire", in the words of president James Polk. But at the time of the Civil War in 1861, only 34 states were formally organized, out of the 50 to be established in the future, which encompassed barely half of the territory (due to the smaller size of the initial former colonies). Eleven of those 34 states, including about 30 percent of total population, formed the Confederate States of America and proclaimed their secession, while still fighting with the rest of the Union for some unorganized territories.

After the defeat of the Confederacy in 1865, internal wars with natives and lawlessness were characteristic of the famous 'Wild West' for several decades. Settlers on the frontier established towns and counties, as well as territorial 
governments combining a locally elected legislature with a governor and other officials sent by the federal government. A territory qualified for statehood if it achieved a population of 60,000 . But during the twenty-five years following the Civil War, federal Congress made a state of only one territory (Colorado), while territorial governments subsisted for decades. Statehood implied citizenship rights including those of voting for their own top officials as well as for he federal president, representatives and senators. But it was not until 1912 that all 48 states covering almost all the territory were formed (while two more, Alaska and Hawaii, were later added in 1958 and 1959).

Nowadays, unincorporated territories still exist, with a local government but with no voting rights for federal offices, in a number of islands in the Caribbean sea and the Pacific ocean. U.S. citizenship is given to the inhabitants of the commonwealths of Puerto Rico and the Northern Mariana Islands, while those in the colonies of Guam, the Virgin Islands, and American Samoa experience other restrictions. There have also been a few cases in which some territories have separated from the USA. The Pacific archipelagos of Micronesia, Marshall Islands, and Palau, which were occupied during WWII by Japan, eventually became independent (the former two in 1986 and the latter in 1994), while maintaining a Compact of Free Association with the United States and the use of the U.S. dollar.

Stabilizing the external borders of the United States was a necessary condition for its internal institutionalization and increasing cohesion. However, keeping the U.S. borders closed has always been a harsh endeavour. In the north-east, trans-border state and provincial cooperation has developed between New England and the Canadian Maritimes. In the north-west, a trans-border economic region called Cascadia includes Seattle in the USA and Vancouver in Canada. In the south-west, San Diego in the USA and Tijuana in Mexico form a single metropolitan area. Large segments of the border with Mexico have never ceased being crossed by legal and illegal traders, traffickers, labourers and migrants.

Attracting forces within a larger space than the United States eventually led to the creation of the Canada-United States Free Trade Agreement in 1989, and the North 
America Free Trade Agreement, also including Mexico, five years later. The development of increasing continental economic relations has not only reduced the strength of the borders, but has also contributed to modifying the internal territorial balance within each country. In Canada, demands for further self-government and independence of Quebec have been facilitated by the expectation that, with better access to the United States markets, it would have economic alternatives and a wider range of options regarding the rest of Canada. In Mexico, some northern lands, thanks to their proximity to the United States, have experienced significant economic growth, while the south remains in poverty and the regional inequalities within the country increase.

\subsection{The states in the EU}

The territorial limits of most state-members of the European Union were drawn prior to their membership of the Union. However, most of these states and their borders are of relatively recent conformation. Of the 27 states, 7 are less than 50 years old, 12 are less than 100 years old, and in total 19 are less than 200 years old, most of them having been created as a result of the desegregation of parts of the Austrian, German, British, Ottoman and Russian empires, as well as the Czechoslovak and Yugoslavian federations. All in all, most states of the EU are about as young as most states of the USA. Only 7 European member-states have more remote origins in previous large empires, Denmark, France, Britain, Spain, Sweden, the Netherlands, and Portugal.

The average area of an EU member-state is $150,000 \mathrm{~km}^{2}$. The population of the initial six member-states is almost half of total population $(47 \%)$. The average state nowadays has a population of about 17 million inhabitants (in contrast to about 6 million for the states in the United States, as mentioned). The differences are huge: the most populated country, Germany, with about 82 million, is two-hundred times more populated than the smallest, Malta, with about 0.4 million inhabitants. 
However, the size of the largest states and the differences between states are somehow reduced by internal decentralization and the strength of regional governments. There are 74 regions with elected governments and assemblies with legislative powers within seven of the largest states in EU, which, together with the mostly medium- and small-sized twenty unitary states, would produce an average of about 5.3 million inhabitants per political unit -a similar size to the average state within the USA and also close to the average independent state in the world, as mentioned.

The European Union formally established in 1993 that the conditions for previously existing states to join are the disposal of stable institutions that guarantee democracy and the rule of law, a functioning economy which can cope with the large markets of the Union, as well as the ability to assume the obligations of membership and put EU rules and procedures into effect. Strengthening the union has indeed led to maintaining and establishing democratic institutions across the continent and in potential new candidates to join. However, the actual fulfilment of these conditions is somewhat uneven. A number of diverse formulas have existed and exist in the territories encompassed by the European Union.

First, many European colonies in Africa, Asia and the Caribbean obtained independence after their metropolis had created the European Community. These included, for the British empire, Belize, Brunei, Hong Kong, Maldives, St Kitts and Nevis; for the French empire, Algeria, Djibouti, Vanuatu; for the Danish empire, Greenland and Faeroe; for the Dutch empire, Guiana (becoming Suriname); for the Portuguese empire, Macau; for the Belgian empire, Congo; and for the Italian empire, Somaliland. The colonies of member-states that remain today are not part of the European Union, but they enjoy 'association' agreements, as is the case of the British dominions in the islands of Anguilla, Bermudas, Cayman, Falkland, Montserrat, Pitcairn, St Helena, Turks \& Caicos, and Virgin, the French dominions of St Barthélemy and St Martin, and the Dutch dominions in Aruba and Antilles.

The so-called 'outermost regions' and other special cases are mostly other islands with colonial origins whose inhabitants, in contrast to those of the above mentioned 
colonies, are EU citizens, but they enjoy special tax exemptions. They include, for Britain, the bailiwicks in the Channel islands, Man and the enclave of Gibraltar; for France, the departments of Guiana, Guadeloupe, Martinique and Reunion, as well as the 'collectivities' of New Caledonia, Mayotte, St Pierre \& Miquelon, Polynesia, and Wallis \& Futuna; for Spain, the autonomous communities of the Canary Islands and the autonomous cities of Ceuta and Melilla; for Portugal, the autonomous regions of Azores and Madeira; for Greece, the Mount Athos; and for Finland, the autonomous province of Alan. (A few of them appear, in spite of their remoteness, on the map of Europe on euro bills).

Finally, while some microstates are members of the European Union, as is the case of Luxembourg and Malta, others are not members but have special relations, including the use of the euro and open borders with their neighbours, as is the case of Andorra, Liechtenstein, Monaco, San Marino, and the Vatican.

Worried by the huge economic inequalities and cultural differences between most European Union member-states and most of the surrounding countries, EU leaders maintain a 'Neighbourhood Policy' including support economic programs and concerns regarding mass migration. On the east, the Russian area of influence extends to several former Soviet republics, Belarus, Georgia, Moldova, Ukraine, as well as Armenia and Azerbaijan in the South Caucasus. Ukraine and Georgia, in particular, are deeply divided societies. Democratizing movements, the so-called 'orange' and 'rose' revolutions, developed in these countries in 2004, but they have remained split between pro-European and pro-Russian segments. While they have been invited to join NATO and offered free trade deals by the EU, Russia has demonstrated its interest and strength by intervening militarily in Georgia and threatening the European Union with cutting its provision of gas through Ukraine.

Beyond the established limits of the EU, the so-called 'Barcelona process' also seeks to build an area of peace and security through the Union for the Mediterranean, which includes the Arab countries of Northern Africa and the Middle East. But the European Union is not trying to enlarge itself with any of those countries. In fact, 
Morocco's bid for membership was rejected in 1987. The EU is only trying to guard its southern frontier as a stable border.

The development of increasing continental integration and the stabilization of external borders modify old internal territorial balances within member-states. Only Germany and Austria were organized as federations upon joining the European Union, as they had derived from the two largest empires in Central Europe. But further processes of decentralization in favour of regional governments took place later in Belgium and have developed in Italy since the 1970s, Spain and France (the latter without legislative powers) since the 1980s, the United Kingdom since the 1990s, and Poland since the 2000s. These processes grow at different paces and with different formulas, but all benefit from the incentives and opportunities for alternative inter-territorial relations provided by membership of the European Union and always move in the direction of increasing decentralization. They are also asymmetric, with some outstanding regions making stronger claims for higher selfgovernment and having special institutional formulas, as in the cases of Bavaria, Flanders, Sicily, Lombardy, Friuli, Catalonia, the Basque country, Corsica, Northern Ireland, Scotland and others.

Inter-territorial cooperation also develops across state borders, leading to the formation of European Commission-sponsored euro-regions. As inter-state borders vanish, neighboring regions within different states tend to coordinate common interests. Currently 61 euro-regions exist, mostly located in the Benelux area, across the German borders with Austria, Czechia and Poland, and across the Scandinavian countries. All in all, as the broader external borders of the European Union tend to consolidate, the narrower internal borders between and within its state-members tend to fade. 


\section{Designing a Federation}

Constitutions for both the United States of America and the European Union were drafted in Conventions especially called for the purpose. In both cases, the constitution-makers focused on the federative characteristics of the union and designed complex structures of division of powers and inter-institutional relations, in contrast to formulas with higher concentration of power typical of nation-states.

Although in the USA there is a political regime misleadingly called 'presidential' and the EU seems to be closer to a 'parliamentary' regime, actually in both cases the institutions hold 'checks and balances' relations with 'vertical' and 'horizontal' divisions of powers. A 'vertical' division of powers implies distribution of competences among governments at different levels, including local-, state- and union-wide levels. In both the USA and the EU the process of federalization emerges from sovereign states ceding powers to new central institutions and establishing mechanisms for shared decisions. In both cases the principles of 'states rights' or 'subsidiarity' are paramount. Federal policy-making is largely a compound of state decision-making.

A 'horizontal' division of legislative, executive and judicial powers foster both cooperative and conflictive relations between different bodies elected or appointed by different ways. It tends to be division of political control, between the Presidency, the House and the Senate in the USA, and between the Commission, the Council and the Parliament in the EU, besides other institutions. In none of the new constitutional arrangements a single institution holding 'sovereignty' or the power to make the ultimate decision can be identified.

Some important differences between the two cases, however, exist. For the United States, the constitutional Convention that gathered in Philadelphia at the end of the eighteenth century was the beginning of the Union. In Europe, in contrast, a constitutional convention was assembled in Brussels at the beginning of the twentyfirst century after a few decades of increasing integration and a number of accumulated constitutional-like treaties. While the new institutions of the American 
Union were created from scratch, at the time of opening the Brussels convention the European Union had a more constraining previous institutional structure, which led the discussion towards adaptive reforms of the already existing framework.

In both the American and the European Conventions, a controversy developed between those in favour of a stronger, federal union and those preferring to maintain only loose, intergovernmental relations or a confederative link. But while the American delegates came from independent states that were just temporarily linked in a confederacy for reasons of self-defence and war, the decisive participants in the European convention represented member-states of the European Union with stronger legal and material links among them. Accordingly, some leaders of independent states in America could credibly threat with not joining the Union or even with seeking new international allies, as actually some delegates did in Philadelphia. In contrast, the costs of leaving the Union were higher for the European participants. Thus in America the small states' delegates became partners of the initial winning coalition in the Convention because without them the project of a union might have failed and there would not have probably been constitution at all. They achieved to preserve important states' rights out of the new federal jurisdiction and also obtained some over-representation in the federal institutional framework. In contrast, in Europe, where the viability of small states out of the Union would be dubious, the larger states were able to prevail more clearly on most important institutional choices.

\subsection{American Union}

The constitutional Convention gathered in Philadelphia from May to September, 1787. It was formed by 55 delegates of 12 of the 13 states (Rhode Island being absent). The result of the Convention was the United States Constitution, which was adopted "in order to form a more perfect Union". It was ratified by most states' conventions within a few months. However, in Rhode Island and North Carolina the constitution was initially refused, by popular referendum and by the state convention 
respectively; only new conventions in these states ratified the constitution after the first United States president and Congress had been elected and ten constitutional amendments had been approved, mostly to satisfy those two and other states' demands. The ten amendments, which were commonly known as the 'Bill of Rights', acknowledged basic individual rights and the rule of law.

However, some of the basic institutional rules were not stably fixed until many decades later. For the House of Representatives, seats were allocated to the states in proportion to the population, initially with a total of 65 seats. During the nineteenth century, the Congress regularly increased the size of the House to account for population growth. But it fixed the number of seats at 435 in 1911. Each state was allowed to choose its own electoral system to elect its House members. Initially, eight of the initial 13 states chose a single state-wide district with plurality rule, a system that produced single-party sweeps and a high number of single-party state systems. Single-seat districts, which permit more diversity of state representatives, have been enforced in all the United States without exception for elections to the House of Representatives only since 1970.

The upper federal chamber, the Senate, is formed by two members per state independently of population. Initially, the senators were elected by the state legislatures, which usually gave strong leverage in federal matters to state governments. Popular election of U.S. senators was established as a general formula for all the states only in 1913.

Regarding the Electoral College for the election of President, the procedures to select the electors are decided by the states themselves. Initially, in most states electors were chosen by the state legislature, a formula which disappeared completely only in 1876. Most states choose now their electors by popular vote in a single state-wide district. But two states replicate the House districts, as well as the state-wide Senate district, Maine and Nebraska. 
Finally, the number of Justices of the Supreme Court was initially six, it changed several times as the expansion of the Union motivated the creation of new judicial circuits, and it was fixed at nine since 1869.

The eve of WWI was a crucial moment for the establishment of federal institutions in the United States. As mentioned, the organization of almost all the territory in 48 states with local self-government and voting for federal offices was completed only in 1912. The stable size of the House of Representatives and the homogeneous election of the Senate all across the Union are of 1911 and 1913, respectively. In addition, federal responsibility for interstate law enforcement began only with the creation of the Bureau of Investigation (later FBI) in 1908. A central banking system existed only after the creation of the Federal Reserve in 1913. So in a late but short period of five years (1908-1913) many important rules initially sketched in the constitution were finally completed.

\subsection{European Union}

A European Convention gathered in Brussels from February 2002 to July 2003, in the intention to merge all the former treaties and design efficient and democratic formulas for the governance of the European Union. The Convention was formed by members of the state parliaments of the 15 member-states and 13 candidate countries, plus a few members of the European Parliament and the European Commission. The project was submitted and somewhat revised at an InterGovernmental Conference formed only by representatives of the state governments from October 2003 to June 2004. As a result, a "Treaty establishing a constitution for Europe" was signed by the heads of State and Government in October 2004.

The European constitution should have been ratified by all state members, but it was soon refused by popular referendums in France and the Netherlands. A new InterGovernmental Conference replaced the failed text with a new Reform treaty, also called of Lisbon, in December 2007. It adopted most innovations of the constitution 
(including the Charter of Fundamental rights for EU legislation, which is roughly equivalent to an enlarged version of the American Bill of Rights), but it was presented as a mere amendment of the former treaties of Rome and Maastricht to prevent a new complicated procedure. Nevertheless, this treaty failed again at being ratified according to the planned schedule, since it was rejected by popular referendum in Ireland in June 2008. A new referendum is planned in Ireland for October 2009.

Some advances in the adoption of Europe-wide common institutional rules have been developed during the last period. In particular, for the direct popular election of the members of the European Parliament, all countries use now some formula of proportional representation, including Britain and France, which use majority rules for state-wide elections. But new distributions of seats among all the 27 states in each of the main institutions, that is, the Parliament, the Commission and the Council of Ministers, as well as some decision rules such as the qualified majority in the Council, were delayed in their enforcement until 2017.

All in all, the leaders of the European Union have shown some will to shape a stable institutional structure beyond the diplomatic relations that are characteristic of intergovernmental organizations. Not yet a federation, however, the EU can be considered to be still an 'empire' with not only unbounded territorial limits, but also different degrees of allegiance of member-states and territories to Union-level processes of decision-making. The option for every state of remaining out of some common commitments and the emphasis on the possibility of "reinforced cooperation" among a small group of members demonstrates that no complete institutional consistency and decision-making cohesion has been attained yet. 


\section{Concluding comments}

Most states have been created as a consequence of disintegration of empires, and some modern empires have been or are being built as an effort of union from previously existing 'sovereign' states. This is the case of the United States of America, which was created by states previously separated from the British empire by uniting themselves into a new Union, and eventually becoming a democratic federation. Likewise, the European Union has been built during the last fifty years by states mostly formed in a previous period at the disintegration of traditional empires.

The building of the democratic empires of the United States of America and the European Union have involved processes of territorial expansion from an initial core of states which have taken place in different periods, but following comparable models and paths. From the initial cores -13 former colonies along the Atlantic coast in North America and 6 member-states in the centre of Europe, respectively--, each empire has expanded its territory over a number of decades until it multiplied the initial founders' territory by about three or four and the population by two. The assimilation of new territories and states required increasing efforts as they are located at increasing distances from the initial centre and have significantly different populations in economic and ethnic terms. In both cases, territorial expansion was able to assimilate new, relatively close units at the beginning, but it had to adopt more flexible formulas of linkage and association with less cohesive territories in the more distant peripheries. For the United States, the process to establish its basic territorial limits developed over more than 60 years, while the European Union has not yet reached that stage after more than 50 years of enlargements.

The expansion of the United States was, given the founding members' eastern location in the continent, mostly westwards. The enlargements of the European Union, in contrast, have been, due to the central location of the founders, first towards the west and the south and later towards the north and the east. During these processes, some territories at the edges of the already integrated area have become 'frontiers' with uncertain future, which have been the subject of rivalry with 
other empires. More stably, the borders of the United States were established at the Atlantic ocean in the east, Canada and Alaska in the north, the Gulf of Mexico in the south, and the Pacific ocean in the west. However, some of these borders, which included some relatively arbitrary bounds from the point of view of geographical accidents and population composition, were conflictive and provoked discomfort and malaise on the other side. Specifically, there have been sustained political instability and massive migrations to the United States from the islands in the Caribbean sea and Central America.

Analogously, the borders of the European Union are now established at the Atlantic ocean in the west, the Arctic ocean in the north, and the Mediterranean sea in the south. But, somewhat undefined and disputed frontiers still exist in the Balkans, with Turkey, and in eastern regions under the influence of the Russian empire. The full membership to the EU of some of these countries may depend on pending democratization and institutionalization, which may make the area a kind of temporary 'Wild East' of the Union. Not integrating some areas might imply the persistence of conflicts, violence and migrations around the European Union.

The capacity of internal institutionalization of the imperial unions strongly depends on the stabilization of their external limits. The average state in the USA has about six million inhabitants. The average state in the EU is much more populated, about 17 million, but the establishment of numerous regional governments with legislative powers within the largest states is approaching the average size of the European territorial communities to the American level, as well as to the average state in the world. The establishment of fixed external borders for a very large empire favors the increase of internal exchanges and reduces the strength of internal borders, thus giving each territory more alternative options of relations with other territories within the Union. Internal trade and the economic specialization of different territories tend to reduce the inter-state economic inequalities previously generated by protective state-level policies, their rivalry and conflicts, as well as favour some broad scale cohesion in cultural terms. The initial independence and claims of sovereignty of the founding states, each with its specific institutional formulas, make 
room for multilateral relations within the framework of a very large federation. States' rights in the USA and the principle of subsidiarity in the EU are guides for the distribution of powers among a 'vertical' set of government levels.

At the federal level, a complex system of 'horizontal' division of powers and checks and balances between separate elected institutions characterize the institutional architecture of both Unions. But while the full institutionalization of all territories of the United States required about 125 years, in the European Union, a consistent, robust and stable constitutional formula has not yet been achieved.

A major implication of territorial and institutional consolidation of a great federation, like the USA and the EU, is its capacity of developing a foreign policy. The USA was initially created as a union against a foreign enemy, the UK, and its hostilities and alliances with other countries depended on this conflict. For a very long period, its foreign policy focused on defining and keeping its borders. Only after its territorial and institutional consolidation as a democratic federation at the beginning of the twentieth century, could the USA develop a broader foreign policy, especially with its participation in WWI and WWII and the Cold War with the USSR. Likewise, the EU was initially created as a union against a foreign enemy, the USSR, and in strong alliance with the USA. This alliance somewhat weakened since the 1970s and especially after the Cold War. But as the EU borders are not yet defined, the EU has not developed a broad and consistent common foreign policy. 


\section{References}

Albgaba, E., J.M. Bilbao and J.R. Fernandez (2007). 'The Distribution of Power in the European Constitution'. European Journal of Operational Research, 176 (1), pp. 752-766.

Ansell, C.K. and G. di Palma eds (2004). Restructuring Territoriality. Europe and the United States Compared. Cambridge and New York: Cambridge University Press.

Bartolini, S. (2005). Restructuring Europe. Centre Formation, System Building, and Political Structuring between the Nation State and the European Union. Oxford: Oxford University Press.

Colomer, J. M. (2002). 'How Political Parties, Rather than Member-States, Are Building the European Union'. in: B. Steunenberg (ed.) Widening the European Union: The Politics of Institutional Change. and Reform. London: Routledge.

Colomer, J. M. (2007). Great Empires, Small Nations. The uncertain future of the sovereign state. London and New York: Routledge.

Colomer, J. M. (2008). 'The European Union: A Federal, Democratic Empire?'. in: J. M. Colomer (ed.) Comparative European Politics $3^{\text {rd }}$ edition. London: Routledge.

Colomer, J. M. and M. Hosli (1997). 'Decision-Making in the European Union: The Power of Political Parties'. Swiss Review of International Economic Relations Aussenwirstchaft, 52, pp. 255-280.

Faust, D. G. (2008). This Republic of Suffering. New York: Random House.

Grofman, B. and D. Wittman (eds.) (1989). The Federalist Papers and the New Institutionalism. New York: Agathon.

Hix, S. (2005). The Political System of the European Union. Basingstoke: Palgrave-Macmillan.

Jillson, C. (1988). Constitution Making: Conflict and Consensus in the Federal Convention of 1787. New York: Agathon.

Keating, M. and J. McGarry (eds.) (2006). European Integration and the Nationalities Question. London: Routledge.

McDonald, F. (2001). States' Rights and the Union: Imperium in imperio, 1776-1876. Kansas: University Press of Kansas.

Menon, A. and M. A. Schain (eds.) (2006). Comparative Federalism: The European Union and the United States in Comparative Perspective. Oxford: Oxford University Press.

Norman, P. (2005). The Accidental Constitution. The Making of Europe's Constitutional Treaty. Brussels: EuroComment.

Nugent, W. (2008). Habits of Empire: A History of American Expansion. New York: Knopf.

Stein, M. (2008). How the States Got their Shapes. New York: HarperCollins.

Turner, F. J. (1920). The Frontier in American History. New York: Henry Holt \& Co.

Zielonka, J. (2006). Europe as an Empire. Oxford: Oxford University Press. 


\section{Recent LEQS papers}

Walker, Neil. 'Multilevel Constitutionalism: Looking Beyond the German Debate'. LEQS Paper No. 8, June 2009

Frankel, Jeffrey. 'The Estimated Trade Effects of the Euro: Why Are They Below Those From Historical Monetary Unions Among Smaller Countries?'. LEQS Paper No. 7, June 2009

Colomer, Josep M.. 'On Building the American and the European Empires'. LEQS Paper No. 6, June 2009

Boeri, Tito. 'Immigration to the Land of Redistribution'. LEQS Paper No. 5, June 2009

Jones, Erik. 'They Have No Idea... Decision-making and Policy Change in the Global Financial Crisis'. LEQS Paper No. 4, May 2009

Frey, Bruno. 'A New Concept of European Federalism'. LEQS Paper No. 3, May 2009

Chalmers, Damian. 'Gauging the Cumbersomeness of EU Law'. LEQS Paper No. 2, May 2009

Bellamy, Richard. 'The Liberty of the Post-Moderns? Market and Civic Freedom within the EU'. LEQS Paper No. 1, May 2009 
LEQS

European Institute London School of Economics Houghton Street

WC2A 2AE London

Email: euroinst.LEQS@lse.ac.uk

http://www2.lse.ac.uk/europeanInstitute/LEQS/Home.aspx 